\title{
THE IMAGE OF GOD IN THE OLD TESTAMENT
}

\author{
Ph.D. Hristea G. KARAIANNIS, \\ Professor of Faculty of Theology, \\ National and Kapodistrian University of Athens, \\ GREECE, \\ E-mail: ckaragiannis@yahoo.gr
}

\begin{abstract}
Although in the Old Testament there is no image and no representation of God in the creation text it is written that God created man in his own image and likeness. Is Man's form God's image? The image and likeness cannot be man's body because God is spirit and has no body and animals have bodies but are not in the image of God. The image refers to the soul and to the mind. The likeness of man to God must be limited to the immaterial part of man. The functional interpretation of the ,imago Dei" understands the image to relate to humanity's role as God's agents in the world. The image of God cannot be regarded as an idiom of man's attitude. It is not a quality in man but a declaration that God had the will to bring to existence a partner. Thus, man becomes God's partner. Nowhere does the Old Testament indicate that the divine image and likeness are lost because of the Fall. The image of God constitutes all that differentiates man from the lower creation. Man has the will, the freedom of choice, self-consciousness, self-transcendence, self-determination, rationality, morality, and spirituality. The image declares the immovable relationship between God and man. Excludes the natural affinity to this relationship and accepts the heterogeneity of the creation with reference to the creator. It is a creation in the image of God rather than a creation as an image of God.
\end{abstract}

Keywords: God; Creation; man; image; likeness; aniconism; soul; mind; body;

\section{INTRODUCTION}

According to the Old Testament God has no image. Ex. 20:4 clarifies: You shall not make for yourself a graven image, or any likeness of anything that is in heaven above, or that is in the earth beneath, or that is in the water under the earth ${ }^{1}$. If it is forbidden for Israel to create an image of God, because he will become idolatrous, then what could be his perception about the image of God. When God talks about His presence he declares that „I am who I am"2 and he testifies His presence via the ark of the covenant ${ }^{3}$ or physical phenomena such as thunders and lightnings or the smoking mountain of Sinai ${ }^{4}$. So, if God in the Old Testament does not permit to create something about his image how can we perceive how he is like?

\footnotetext{
${ }^{1}$ Comp. Deut. 5:8.

${ }^{2}$ Ex. 3:14.

${ }^{3}$ Ex. 25:22, Num. 7:89, 10:33-35, Josh. 3:3, 15-17, 5:6-12, 6:12-16, 18:1, I. Sam. 1:3, 3:3, 4:4, 5-22, 6:11, II. Sam. 6:2, I. Kgs 8, 19:10, I. Chr. 13:13, 16, 15:28-29, 28:2, 11, II. Cgr. 6:41,

${ }^{4}$ Ex. 20:18.
} 


\section{THE IMAGE OF GOD IN THE OLD TESTAMENT}

In the entire Old Testament there are only three explicit references to the imago Dei notion (Genesis 1:26-27; 5:1; and 9:6) ${ }^{5}$. Furthermore, these references are all found in that section of Genesis (chapters 1-11) known as the ,primeval history”. Gen. 1:26-27 constitute the locus classicus of the doctrine of imago Dei, the notion that human beings are made in God's image:

O' 26 And God said, Let us make man according to our image

and likeness, and let them have dominion over the fish of the sea,

and over the flying creatures of heaven, and over the cattle and all the earth, and over all the reptiles that creep on the earth.

27 And God made man, according to the image of God he made him, male and female he made them.

The concept of the image of God, implied or expressed, underlies all revelation ${ }^{6}$. But as Henry and Feinberg point out the Bible does not define the precise content of the image of $\operatorname{God}^{7}$. Maybe that is the reason why as Snaith argues many „orthodox" theologians through the centuries avoided to „touch" the phrase the image of God (imago Dei) ${ }^{8}$. That does not exclude biblical researches to develop the research about this idea. Middleton mentions that ,in the last thirty years of the twentieth century the functional understanding of the image of God became the virtual consensus in the field"9.

At the very beginning, it has to be said that the interpretation of the image of God among theologians makes a clear distinction between the body and the image, establishing the dualistic reading of the human race. Clark notes that the image and likeness cannot be man's body, because (1) God is spirit and has no body, and (2) animals have bodies but are not in the image of $\operatorname{God}^{10}$. Clarke believes that the image refers to the soul and to the mind, not to a body. His emphasis is: „God was now producing a spirit, and a spirit, too, formed after the perfections of his [that is, God's] nature" ${ }^{11}$. For Keil and Delitzsch the image of God refers to the self-conscious personality of $\operatorname{man}^{12}$. Chafer suggests the image of God is constituted only on the basis of the spiritual ${ }^{13}$. On the other hand, the likeness of man to God must be limited to the immaterial part of man, because God is incorporeal ${ }^{14}$.

Male and female, Adam and Eve, were created in the image of God. Brunner and Barth held a relational view of the image ${ }^{15}$. The functional interpretation of the imago Dei understands the image to relate to humanity's role as God's royal agents in the world. Man, as the image of God, is placed on earth as God's representatives. Skinner ${ }^{16}$ suggests that the

\footnotetext{
${ }^{5}$ C. L. Feinberg, „The Image of God”, Bibliotheca Sacra 129 (1972), 515: 236.

${ }^{6}$ J. Orr, „God, Image of,” The International Standard Bible Encyclopaedia, J.Orr, et al., (ed.), (1929), 1264.

${ }^{7}$ C. F. H. Henry, God, Revelation and Authority, Vol. II God Who Speaks and Shows: Fifteen Theses, Part

One, Waco, Texas: Word 1976, p. 125. C. L. Feinberg, „The Image of God", 515: 238.

${ }^{8}$ N. Snaith, „The Image of God”, Expository Times 86 (October 1974-September 1975) 24.

${ }^{9}$ R. J. Middleton. The Liberating Image: The Imago Dei in Genesis 1, Grand Rapids: Brazos Press 2005, p. 29.

${ }^{10}$ G. H. Clark, „The Image of God in Man”, Journal of the Evangelical Theological Society, XII (1969), 216.

${ }^{11}$ A. Clarke, The Holy Bible, Containing the Old and New Testaments, New York 1837, p. 38.

${ }^{12}$ C. F. Keil and F. Delitzsch, The Pentateuch, Vol. I of Biblical Commentary on the Old Testament, J. Martin (trans.), Edinburgh 1866, pp. 63-64.

${ }^{13}$ A. Altmann, ,Homo Imago Dei in Jewish and Christian Theology”, Journal of Religion, XLVIII (July, 1968), 235-239, 243-244.

${ }^{14}$ L. S. Chafer, Systematic Theology, Dallas 1947, pp. 181, 184.

${ }^{15}$ M. J. Erickson, Christian Theology, Grand Rapids, MI: Baker Academic 1998, pp. 524-525.

${ }^{16}$ J. Skinner, A Critical and Exegetical Commentary on Genesis: The International Critical Commentary, S. R. Driver, A. Plummer and C. A. Briggs (ed.), Edinburgh 1910, p. 32
} 
image qualifies man for dominion, he affirms that such rule is a consequence, and not the essence of the image of God. Leupold remarks, „The double modifying phrase, 'in our image, after our likeness,' is nothing more than a phrase which aims to assert with emphasis the idea that man is to be closely patterned after his Maker"17.

Brunner distinguishes between two senses of the image of God: the formal and the material. The formal image is the humanurn that which makes a person human, distinguishing the human from the animal. The formal image is man's constitution as a rational being, responsible and free. Man as sinner has not lost this aspect of the image of God. In fact, it is presupposed in the ability to sin. While man's freedom is limited as compared with God's freedom, it is genuine. The image in this formal sense has not been touched in the least, says Brunner ${ }^{18}$. He points out that even the formal aspect is not structural; it is relational. Brunner uses the analogy of a mirror to clarify the distinction between the formal and material aspects of the image of God. When we bear the image of God in the material sense, we are in positive and responsive relationship to him. Brunner sees this aspect of the image to the reflection in a mirror.

Eichrodt ${ }^{19}$ suggested that the ancient traditions of the Old Testament had a different perception about the image understanding it as more physical. On the other hand the tradition of the Priestly Code (P) gave a spiritual sense to the image. His idea has been accepted later by Schellenberg ${ }^{20}$ who pointed out that $\mathrm{P}$ understood the imago Dei beyond a functional focus on humankind as the lords over the animals. The biblical text focuses on the way that God created man and not if he is similar to Him. God as the the creator of all men is associated with all of them and not with small royal minority.

Von $\operatorname{Rad}^{21}$ believes ,the image of God in man contains no direct explanation about the form which specially constitutes it; its real point is rather the purpose for which the image was given to man...his status as lord in the world". The image fundamentally means „the pattern on which [human beings are] fashioned is to be sought outside the sphere of the created." According to Clines the Old Testament never says that humanbeing was created in the image of $\mathrm{God}^{22}$.

Bonhoeffer ${ }^{23}$ emphasizes that the expression in the image of God means rather the relationship between God and man and not a possession. „Humankind's likeness to God lies in his capacity to be addressed as a 'thou' and to respond to the divine word" ${ }^{24}$. For Erickson ,the existence of a wide diversity of interpretations is an indication that there are no direct statements in Scripture to resolve the issue. Our conclusions, then, must necessarily be reasonable inferences drawn from what little the Bible does have to say on the subject" ${ }^{\prime 25}$. Auld $^{26}$ focuses on Genesis 5:1-3 and 9:1-7 and regards these two passages to be the source texts for 1:26-31. His textual analysis introduced the idea that they were formulated to

\footnotetext{
${ }^{17}$ H. C. Leupold, Exposition of Genesis, Columbus: Wartburg Press 1942, p. 88.

${ }^{18}$ E. Brunner, The Christian Doctrine of Creation and Redemption, London: Lutterworth 1952, pp. 55-57.

${ }^{19}$ W. Eichrodt, Theology of The Old Testament Vol. II., London SCM Press 1967, p. 122.

${ }^{20}$ A. Schellenberger, „Humankind as the 'image of God'. On the Priestly predication (Gen 1:26-27; 5:1; 9:6) and its relationship to the ancient Near Eastern understanding of images", Theologische Zeitschrift 65 (2009) 97-115.

${ }^{21}$ G. Von Rad, Old Testament Theology Volume 1, Edinburgh: Oliver \& Boyd 1973, pp. 143-146.

22 D. J. A. Clines. „The Image of God in Man”, Tyndale Bulletin 19 (1968), 99.

${ }^{23}$ D. Bonhoeffer, Creation and fall, London / New York 1959, pp. 33-38.

${ }^{24}$ B. S. Childs, Biblical Theology of the Old and New Testaments: Theological reflection on the Christian Bible, Minneapolis: Fortress 1993, p. 568.

${ }^{25}$ M. J. Erickson, Christian Theology, vol. 1, Grand Rapids: Baker 1987, pp. 512-513.

${ }^{26}$ G. Auld, „Imago Dei in Genesis: Speaking in the Image of God”, Expository Times 116 (2005) 259-262.
} 
function as a new prologue to the book of Genesis in order to place humans further from animals and closer to God.

According to Middleton ${ }^{27}$ Gen 1:26 is the key to understand the idea of the imago Dei. The syntax of the passage remarks the verb ,to rule” as the main purpose of man. As a result, humankind has been created to dominate in purpose and not as a consequence of the imago Dei. Chapter 1 of the book of Genesis declares that man has been created to be a representative and agent of God in the world and to share God's rule on the earth.

For Barth the phrase in the image of God is not referring only to the relationship between man and God, but between men as well. The image of God cannot be regarded as an idiom of man's attitude. It is not a quality in man but a declaration that God had the will to bring to existence a partner. Thus, man becomes God's partner. Barth emphasized the „Ithou" or „face-to-face" relation as in the divine life. Man cannot be created in the image of God because God is ,totally Other". As the time passed he changed this idea and found a divine image in $\operatorname{man}^{28}$. The presence of Jesus Christ gave a more substantial meaning: the image of God consists in being for others, in constructing a strong relationship with others.

Some researchers believe Gen. 1:1-2:3 consists a special narrative unit which reflects the idea that the image of God in man has a corporeal meaning. The analysis of this this opinion deliveres the „royal" flavour of the biblical text, which presents man as the appointed by God ruler to dominate over the cosmos. This picture has also been reflected by the prophet Isaiah who sees Yahweh as ,,seated on a throne, high and exalted"29.

McFague's opinion about God as a ruler reflects the icon of a Monarch who stands above all and rules his kingdom, a picture obviously crucial for the royal interpretation of the image $^{30}$. This understanding of the image occurs also in ancient Near East where the kings were the representatives of God in the earth as the living images of $\operatorname{God}^{31}$. According to this opinion the idea about the image of God reflects the influence of the ancient Near Eastern perspectives. Walton, points out that in the ancient Near East it was believed that the image of God did the work of God in the world ${ }^{32}$. As a result it is obvious one should examine to what extent the biblical text has been influenced by the ancient Near Eastern understanding of the imago Dei.

In the four thousand year old Sumerian creation myth is stated:

O my mother, the being who you named is there; associate the image of the gods with him, mix the nucleus of the clay above the primal ocean. The gods and princely figures will thicken the clay,

\footnotetext{
${ }^{27}$ J. R. Middleton, The liberating image: the 'Imago Dei' in Genesis 1, Grand Rapids: Brazos 2005.

${ }^{28}$ K. Barth, Church Dogmatics, Edinburgh: T. and T. Clark 1958, vol. 3, part 1, p. 185.

${ }^{29}$ Is. 6:1. P. D. Miller, Jr., „The Sovereignty of God”, The Hermeneutical Quest: Essays in Honor of James Luther Mays on His Sixty-Fifth Birthday, D. G. Miller (ed.), Allison Park, Penn.: Pickwick Publications 1986, pp. 129-144; G. E. Wright, The Old Testament and Theology, New York: Harper and Row 1969, pp. 97-150; J. S. Chestnut, The Old Testament Understanding of God, Philadelphia: Westminster, 1968, pp. 70-81. G. V. Smith, „The Concept of God/the Gods as King in the Ancient Near East and the Bible”, Trinity Journal 3 (1982) 1, 18-38.

${ }^{30}$ S. McFague, Models of God: Theology for an Ecological, Nuclear Age, Philadelphia: Fortress 1987, pp. 6369.

${ }^{31}$ P. J. Gentry and S. J. Wellum. Kingdom through Covenant: A Biblical-Theological Understanding of the Covenants, Wheaton, IL: Crossway 2012, pp. 192-193.

${ }^{32}$ J. H. Walton, Ancient Near Eastern Thought and the Old Testament: Introducing the Conceptual World of the Hebrew Bible, Grand Rapids, MI: Baker Academic 2006, p. 212.
} 
But you must give life to the limbs ${ }^{33}$.

The term for tselem in Akkadian is salmu. Salmu is used in association to the statues of kings and dignitaries, as well as the images of deities ${ }^{34}$. Furthermore, the Akkadian king is called a salmu, as the image of a deity - Enuma Elish $1: 15-16^{35}$. In addition to this the Egyptian Instruction of Merikare presents humans as the representatives of gods in the earth and Pharaoh as the bearer of the image of the sun $\operatorname{god}^{36}$ :

Well tended is mankind-god's cattle,

He made sky and earth for their sake, He subdued the water monster,

He made breath for their noses to live. They are his images, who came from his body, He shines in the sky for their sake;

He made for them plants and cattle, Fowl and fish to feed them.

Merill believes that such a perception occurs as well in the Akkadian and Aramaic Tell Fekheriye inscription ${ }^{37}$. According to Van Leeuwen ${ }^{38}$ it is possible that the author of the biblical text, surrounded by perceptions which regarded the king as a symbol of the power of a deity, has been affected and as a result imported such ideas to the Old Testament.

Gen. 1:26 is the crown of the creation. The climax of creation is reached in with the creation of the man. Dempster states, ,the rest of the canon assumes the royal overtones of Genesis 1, indicating the unique authority assigned to the primal couple, and thus to all humanity" 39 .The creation of the man is underlying the two ways relationship between God and man. God's first utterance is „Let Us make man in Our image, according to Our likeness." The plural „let us make” is a plural of majesty for God Elohim. This decision of God defines man in relation to Him. Then God decrees, „Let them rule...” and places man to name all animals. This relates man to creation. The biblical text shows that man must actualize his relationship with God by the way he relates to the world around him.

This relationship between the Creator and man has a beginning. God's decision „Let us make man" shows God's purpose. The result of this action is God's doing of man ,in our image, according to our likeness". It is God who sets up this relation. Man was created in the image of God, by God's own will and that is out of what God is in himself. After the creation of the world man comes to the proscenium as the final creation. It is only man who is being created in the image of God. Dominion over the world was given only to man. Does this fact inform us about God's image? The answer is no!

Thielicke believes that ,the divine likeness is thus a relational entity because it is manifested in man's ruling position vis-à-vis the rest of creation, or better, because it consists in this manifestation, in this exercise of dominion and lordship."

Did the Fall of man effect the image of God? Nowhere does the Old Testament indicate that the divine image and likeness are lost. Biblical text declares that after the Fall

\footnotetext{
${ }^{33}$ W. Beyerlin, Near Eastern Religious Texts Relating to the Old Testament, Philadelphia: Westminster 1978, p. 77.

${ }^{34}$ E. H. Merrill, ,Image of God”, T. D. Alexander \& D. W. Baker (eds.), Dictionary of the Old Testament: Pentateuch. Downers Grove: InterVarsity Press 2003, p. 442. (pp. 441-445).

${ }^{35}$ R. C. Van Leeuwen, „Form, Image”, W. A. Van Gemeren (ed.), New International Dictionary of Old Testament Theology and Exegesis Volume 4, Grand Rapids: Zondervan 1997, p. 644, (pp. 643-648).

${ }^{36}$ M. Lichtheim, Ancient Egyptian Literature 3 vols., Berkeley: University of California 1973-1980.

${ }^{37}$ E. H. Merrill, „Image of God”, T. D. Alexander \& D. W. Baker (eds.) Dictionary of the Old Testament: Pentateuch. Downers Grove: InterVarsity Press 2003, p. 442, (pp. 441-445).

${ }^{38}$ R. C. Van Leeuwen, „Form, Image”, p. 644.

${ }^{39}$ S. G. Dempster, Dominion and Dynasty: A Theology of the Hebrew Bible, Downers Grove: InterVarsity Press 2003, p. 60.
} 
man „is still the "work and creature of God" 40 . The New Testament refers to the new creation, to the restoration of the image (cf. 1 Cor. 15:49). Christ is the pattern of this restoration. The principle emphasis in Pauline theology is the restoration of the image (cf. 2 Cor. 3:18) ${ }^{41}$. Man has been endowed with God's likeness, but he cannot achieve this likeness by his own will and power. God gives any likeness and that is proofed by Jesus Christ.

Is Jesus Christ the image of God? The relative passages are 2 Cor. 4:4; Col. 1:15-17; and Hebr. 1:2, 3. These passages are dealing with Christ not so much as the incarnate Savior as the eternal Son. But it has to be said that when the Bible represent man in the image of God, it is of the Godhead, not of Christ exclusively. That happens because man cannot be equated with God. Chereso points out: „This is because man can never achieve equality or identity of nature with God. Only the Son is so perfect an image of His Father as to be equal to, and identical in nature with, Him. Hence it is that the Word is called the image of God, while man is said to be created in that image" 42 .

The image of God constitutes all that differentiates man from the lower creation. Man has the will, the freedom of choice, self-consciousness, self-transcendence, selfdetermination, rationality, morality, spirituality and nephesh - psychi soul. However, through the anthropomorphism man looks at God because of his human nature. This nature and essence determines the perspective and the image by which man ascribes to God. The Israelite could not speak about God without an anthropomorphism. For Him God has face, eyes, ears, mouth, hands and legs" 43 . However, this does not mean that everything is subjectivism. Man's perception cannot do away with subjectivism because the subject knower is always involved in the process of arriving at knowledge. To know is to enter into a relation with an object of knowledge. In other words, knowing presupposes two things; the subject-knower and the object to be known.

\section{CONCLUSIONS}

1. The image of God is universal within the human race. The first and universal man, Adam, not a portion of the human race, was made in the image of God.

2. The image of God has not been lost as a result of sin or specifically the Fall. The presence of the image and likeness in the non-Christian is assumed. As a result, the image of God is not something accidental or external to human nature. It is something which is connected with humanity.

3. There is no indication that the image is present in one person to a greater degree than in another. For example high intelligence, is not evidence of the presence or degree of the image.

4. The image is not correlated with any variable. For example, there is no direct statement correlating the image with development of relationships, nor making it dependent upon the exercise of dominion.

5. In light of the foregoing considerations, the image should be thought of as primarily substantive or structural. The image is something in the very nature of man, in the way in which he was made. It refers to something man is rather than something he has or

\footnotetext{
${ }^{40}$ Deut. 32:6; Isa. 45:11; 54:5; 64:8; Acts 17:25; Rev. 4:11; Job 10:8-12; Ps. 139:14-16. G. C. Berkouwer, Man: The Image of God, p. 133.

${ }^{41}$ Rom. 8:29; Eph. 4:24; Col. 3:10.

${ }^{42}$ C. J. Chereso, „Image of God”, New Catholic Encyclopedia, W. J. McDonald, et al., (ed.) VII (1967), p. 369.

${ }^{43}$ Gen. 3:8; 32:30; Ex. 33:3, I. Sam. 5:11; II. Kgs 19:16; Is. 52:10, Zech. 4:10.
} 
does. By virtue of his being man, he is in the image of God; it is not dependent upon the presence of anything else.

6. The image refers to the elements in the makeup of man which enable the fulfillment of his destiny. The image is the powers of personality which make man, like God, a being capable of interacting with other persons, of thinking and reflecting, and of willing freely.

Finally, the image declares the immovable relationship between God and man. Excludes the natural affinity to this relationship and accepts the heterogeneity of the creation with reference to the creator. It is a creation in the image of God rather than a creation as an image of $\operatorname{God}^{44}$.

\section{BIBLIOGRAPHY:}

[1] Altmann, „Homo Imago Dei in Jewish and Christian Theology”, Journal of Religion, XLVIII (July, 1968),

[2] Clarke, The Holy Bible, Containing the Old and New Testaments, New York 1837,

[3] Schellenberger, „Humankind as the 'image of God', Theologische Zeitschrift 65 (2009)

[4] S. Childs, Biblical Theology of the Old and New Testaments: Theological reflection on the Christian Bible, Minneapolis: Fortress 1993,

[5] F. H. Henry, God, Revelation and Authority, Vol. II God Who Speaks and Shows: Fifteen Theses, Part One, Waco, Texas: Word 1976

[6] F. Keil and F. Delitzsch, The Pentateuch, Vol. I of Biblical Commentary on the Old Testament, J. Martin (trans.), Edinburgh 1866,

[7] J. Chereso, „Image of God”, New Catholic Encyclopedia, W. J. McDonald, et al., (ed.) VII (1967

[8] L. Feinberg, „The Image of God”, Bibliotheca Sacra 129 (1972),

[9] Bonhoeffer, Creation and fall, London / New York 1959,

[10] J. A. Clines. „The Image of God in Man”, Tyndale Bulletin 19 (1968), 99.

[11]Brunner, The Christian Doctrine of Creation and Redemption, London: Lutterworth 1952, pp. 55-57.

[12]H. Merrill, „Image of God”, T. D. Alexander \& D. W. Baker (eds.), Dictionary of the Old Testament: Pentateuch. Downers Grove: InterVarsity Press 2003,

[13] Auld, „Imago Dei in Genesis: Speaking in the Image of God”, Expository Times 116 (2005)

[14]E. Wright, The Old Testament and Theology, New York: Harper and Row 1969,

[15]H. Clark, „The Image of God in Man”, Journal of the Evangelical Theological Society, XII (1969),

[16]V. Smith, „The Concept of God/the Gods as King in the Ancient Near East and the Bible”, Trinity Journal 3 (1982)

[17] Von Rad, Old Testament Theology Volume 1, Edinburgh: Oliver \& Boyd 1973.

[18]C. Leupold, Exposition of Genesis, Columbus: Wartburg Press 1942,

[19] H. Walton, Ancient Near Eastern Thought and the Old Testament: Introducing the Conceptual World of the Hebrew Bible, Grand Rapids, MI: Baker Academic 2006,

[20] Orr, „God, Image of,” The International Standard Bible Encyclopaedia, J.Orr, et al., (ed.), (1929),

[21]R. Middleton, The liberating image: the 'Imago Dei' in Genesis 1, Grand Rapids: Brazos 2005.

[22] S. Chestnut, The Old Testament Understanding of God, Philadelphia: Westminster, 1968,

[23] Skinner, A Critical and Exegetical Commentary on Genesis: The International Critical Commentary, S. R. Driver, A. Plummer and C. A. Briggs (ed.), Edinburgh 1910,

[24] Barth, Church Dogmatics, Edinburgh: T. and T. Clark 1958, vol. 3, part 1

[25] S. Chafer, Systematic Theology, Dallas 1947,

[26] J. Erickson, Christian Theology, Grand Rapids, MI: Baker Academic 1998,

[27]Lichtheim, Ancient Egyptian Literature 3 vols., Berkeley: University of California 1973-1980.

[28] Matsouka, Dogmatic and Symbolic Theology B', Thessaloniki: Pournara 2010,

${ }^{44}$ N. Matsouka, Dogmatic and Symbolic Theology B', Thessaloniki: Pournara 2010, pp. 195-196 (in Greek). 
[29] Snaith, „The Image of God”, Expository Times 86 (October 1974-September 1975)

[30]D. Miller, Jr., „The Sovereignty of God”, The Hermeneutical Quest: Essays in Honor of James Luther Mays on His Sixty-Fifth Birthday, D. G. Miller (ed.), Allison Park, Penn.: Pickwick Publications 1986,

[31]J. Gentry and S. J. Wellum. Kingdom through Covenant: A Biblical-Theological Understanding of the Covenants, Wheaton, IL: Crossway 2012,

[32]C. Van Leeuwen, „Form, Image”, W. A. Van Gemeren (ed.), New International Dictionary of Old Testament Theology and Exegesis Volume 4, Grand Rapids: Zondervan 1997, p

[33] J. Middleton. The Liberating Image: The Imago Dei in Genesis 1, Grand Rapids: Brazos Press 2005 ,

[34]G. Dempster, Dominion and Dynasty: A Theology of the Hebrew Bible, Downers Grove: InterVarsity Press 2003,

[35] McFague, Models of God: Theology for an Ecological, Nuclear Age, Philadelphia: Fortress 1987 ,

[36]W. Beyerlin, Near Eastern Religious Texts Relating to the Old Testament, Philadelphia: Westminster

[37] W. Eichrodt, Theology of The Old Testament Vol. II., London SCM Press 1967. 